\title{
Does Board Monitoring Affect Integrated Reporting Disclosure for Better Transparency and Sustainability?
}

\author{
Sunarti Halid ${ }^{1}$, Radziah Mahmud², Nor Balkish Zakaria ${ }^{3}$, Rahayu Abdul Rahman ${ }^{1, *}$ \\ ${ }^{1}$ Faculty of Accountancy, Universiti Teknologi Mara, Perak Branch, Tapah Campus, Malaysia \\ ${ }^{2}$ Faculty of Accountancy, Universiti Teknologi Mara, Selangor Branch, Puncak Alam Campus, Malaysia \\ ${ }^{3}$ Accounting Research Institute, Universiti Teknologi Mara, Selangor, Malaysia
}

Receive June 7, 2021; Revise August 26, 2021; Accepted September 21, 2021

\section{Cite This Paper in the following Citation Styles}

(a): [1] Sunarti Halid, Radziah Mahmud, Nor Balkish Zakaria, Rahayu Abdul Rahman, "Does Board Monitoring Affect Integrated Reporting Disclosure for Better Transparency and Sustainability?," Universal Journal of Accounting and Finance, Vol. 9, No. 5, pp. 1049 - 1057, 2021. DOI: 10.13189/ujaf.2021.090515.

(b): Sunarti Halid, Radziah Mahmud, Nor Balkish Zakaria, Rahayu Abdul Rahman (2021). Does Board Monitoring Affect Integrated Reporting Disclosure for Better Transparency and Sustainability?. Universal Journal of Accounting and Finance, 9(5), 1049 - 1057. DOI: 10.13189/ujaf.2021.090515.

Copyright@2021 by authors, all rights reserved. Authors agree that this article remains permanently open access under the terms of the Creative Commons Attribution License 4.0 International License

\begin{abstract}
The growing of stakeholders' demand for better corporate transparency has derived firms to adopt integrated reporting. Thus, this study aims to examine the impact of firm's board of directors on integrated reporting practice. In particular, this study investigates how board characteristics; board size, board independence, board activity and board gender diversity influence the degree of integrated reporting disclosure of Malaysian commercial banks. Consistent with prior research, this study uses a disclosure index based on International Integrated Reporting Council Framework to measure integrated reporting disclosure. Using a sample of Malaysian commercial banks from 2013 to 2017 , the results show that board size is significantly negative associated with integrated reporting disclosure. Other board characteristics, however, are not associated with integrated reporting disclosure. Our findings provide insights for regulators in designing more effective corporate governance mechanisms that promote better integrated reporting practice.
\end{abstract}

Keywords Integrated Reporting, Disclosure, Corporate Governance, Board of Directors, Malaysia

\section{Introduction}

In recent years, integrated reporting (IR) has received considerable attention from regulators, shareholders, and academics, in response to the limitation of traditional corporate reporting system which is unable to provide a holistic view of firm's performance. IR is a new reporting and communication tool adopts by the firm that integrates both financial and non-financial performances [1]. Given the comprehensive information of the report, Malaysian government promotes listed firms of the country to adopt IR to ensure greater transparency and efficiency in disseminating information to the firm's stakeholders. It is because such report allows firm to disclose key information; financial, non-financial, qualitative, quantitative information in providing a complete view on how firm creates its value in order to assist investors to make better informed decisions.

IR has gathered significant interest due to its strategic importance to companies across the industries. In today's competitive market, IR plays important roles to overcome the weaknesses and limitations of traditional corporate reporting system that segregates financial and sustainability information by presenting a single integrated report [2,3]. Indeed, International Integrated Reporting Council (IIRC) stresses that IR that has both financial and sustainability information will further meet investors' needs for information by providing a more complete firm's performance.

Prior studies highlight the role of board of directors in promoting corporate disclosure including IR practice. As a representative of shareholders and other stakeholders, 
firms with effective board are expected to disclose more information to ensure long term corporate sustainability. Empirical research that examines on the association between firm's board of directors and corporate disclosure including IRD, however, shows mixed results [4-9], thus needs further analysis on such relationship. In addition, very limited studies on IRD and its determinants among emerging markets including Malaysia. Therefore, this study aims to examine the degree of IRD in Malaysia and how board of directors affects such practice.

Our study focuses on the adoption of IR in Malaysia as there is an increasing trend of firms opting for the issuing of this type of voluntary report in the country. Based on a survey done by PWC Malaysia on 30 top firms' annual reports in 2013, it is pointed out that Malaysian listed firms have the basic elements or representations of IR, but they still have a long way to truly embrace IR [10]. Given that, our study delves into the role of firm's board in shaping IR practice of Malaysian commercial banks. Our study chooses financial sector, in particular banking sector in Malaysia as a research setting because it represents one of the riskiest sectors for investment in the country. According to [11], the risk nature of the industry motivates management to publish report that provide superior quality information to the stakeholders in explaining the potential benefits that they have.

The results obtained have shown that the only governance structure that influences the IRD is the board size. In addition, the results indicate that bank-specific characteristics; size, growth, and leverage have a significant relationship with the degree of IRD of Malaysian commercial banks. Our study contributes to the IR literature in two ways. Firstly, it provides definitions of some IR principles and content elements. Secondly, stemming from this definition, it proposes a methodology to measure the IRD level and test its connections to some board characteristics.

This study proceeds as follows. Section two comprises a review of prior studies on IRD and development of the hypotheses. Section three contains the research methodology followed by findings and discussion. The final section concludes the study.

\section{Literature Review \& Hypotheses}

\subsection{Integrated Reporting Disclosure}

Corporate disclosure both mandatory and voluntary play important roles in reducing agency conflicts and information asymmetries result from separation of ownership and control [3]. In response to the stakeholders demand on high quality reporting system that is able to provide financial and non financial information, the management publishes various reports such as financial statements, management reports, corporate social responsibility reports as well as corporate governance reports to fulfill the need of the firm stakeholders [12]. IR is viewed as an innovative and effective reporting tool that offers various benefits include medium of communication to firm's stakeholders enhancing and reflecting firm's sustainable goals and strategies[13]; acts as comprehensive report that mitigates firm's reputational risks and improves the quality of corporate reporting system [2].

IIRC [2] highlights on the components of IR that should be published by the firms includes; (1) organizational overview and external environment; (2) governance; (3) business model; (4) risks and opportunities; (5) strategy and resource allocation; (6) performance; (7) outlook; and (8) basis of preparation and presentation. The content of the IR is built upon those elements. Given the recommended eight components by IIRC, IR is able to overcome the criticism of traditional reporting practices as the report offers more comprehensive financial and non financial information to firm stakeholders which in turn create greater confidence in the information. This also leads for better management decisions of resources allocation, risk management, and future business's strategies [14].

Prior studies highlight various corporate governance factors significantly affect the degree of corporate disclosure including integrated reporting disclosure. One of the factors is firm's board of directors. Agency theory suggests that board of directors as major internal control mechanism that plays important role in safeguarding the interests of firms stakeholders. The board is responsible in monitoring management decisions, organizational policies and strategies. Futher, in ensuring management fulfills shareholders and other stakeholder' needs and expectations, effective board is more likely to encourage IR practice.

\subsection{Board Size}

Jensen [15] argues that a number of directors are major contributors for board effectiveness in reducing agency problems and controlling managerial opportunism. However there are conflicting views on the relationship between board size and its effectiveness. Agency theory suggests that a larger board plays more effective monitoring roles as it has greater number of directors who possess more expertise and valuable experiences. Indeed, according to [16] effective board improves the quality of corporate reporting as board encourage management to provide more financial and non financial disclosure. Some scholars however argue that board that has more than eight members is not effective in monitoring firm management as it has more conflicts and coordination related problem [17]. Prior studies such as [18-20] document that board size increase the degree of corporate disclosure. Given that, we develop our first hypothesis as the following: 
Hypothesis 1: There is a positive relationship between the number of directors on board and the degree of IRD for commercial banks in Malaysia.

\subsection{Board Independence}

Agency theory highlights on the important of composition of independent directors in enhancing board's effectiveness [15]. It is because independent directors on board will safeguard the welfare of firm's stakeholders by encourage management to provide comprehensive disclosure to assist them in making decision. A review of prior studies on the impact of independent directors on corporate disclosure document mixed results. For example, [8][14] show a negative relationship between proportion of independent directors on board and disclosure. Meanwhile, other studies [6][9] indicate that board independence positively affects corporate disclosure. Nevertheless, based on the above theory, we hypothesized that:

Hypothesis 2: There is a positive relationship between the proportion of independent directors on board and the degree of IRD for commercial banks in Malaysia.

\subsection{Board Activity}

Board activity please paraphrase itwhich normally proxy by a number of board's meeting, signal for board's efficiency in safeguarding role. Board meeting is a platform for the directors to communicate, consult and monitor firm's management. Thus, more frequent meeting by the board will result in more effective their monitoring roles which leads to a higher quality of corporate reporting including information disclosure. Empirical studies $[21,22]$ seem consistent to the above argument by showing positive and significant relationship between board meeting and corporate disclosure. Given that, we propose the following hypothesis:

Hypothesis 3: There is a positive relationship between the board's activity and the degree of IRD for commercial banks in Malaysia.

\subsection{Board Gender Diversity}

Board gender diversity also called as ferminization of board affects the degree of corporate disclosure. Indeed, the presence of female directors enhances board effectiveness as they carry communal leadership style which promotes ethical decision making. Given that, female directors are more sensitive to certain organizational strategies or policies that have significant impact to firm's stakeholders including corporate social responsibility and environmental issues. Different focus, ethical values and leadership style of female directors add value to the board and lead for better supervision for corporate disclosure. Prior studies [9][23]document the effect of female directors on corporate disclosure. In general, empirical results show that the amount of information disclosures increase with the proportion of female representation on board. Thus, in this study we propose the following expectation:

Hypothesis 4: There is a positive relationship between the board's gender diversity and the degree of IRD for commercial banks in Malaysia.

\section{Research Method}

\subsection{Sample Selection and Data Collection}

The sample of our study consists of eight (8) commercial banks listed on Bursa Malaysia; Hong Leong Bank, Hong Leong Financial Group, AMMB Holdings, CIMB Group Holdings, Malayan Banking, Public Bank, RHB Bank Bhd and Alliance Bank Malaysia for the period 2013 to 2017. The selection of the sample is based on the market capitalization of the bank in the year 2017 to represent the largest and significant players of the industry. Both data required for our study; board of directors, firms-specific characteristics and IR disclosure are collected from the Thomson Reuters Eikon database and annual reports.

\subsection{Dependent Variable}

The dependent variable of our study is integrated reporting disclosure (IRD). Following [24], we measure IRD using a disclosure index that consists of fifty (50) items from seven (7) categories developed based on framework issued by IIRC [2]. The seven categories are organizational overview and external environment, governance, business model, risk and opportunities, strategies and resource allocation, performance and outlook. The contents of disclosure index are presented in Table 1.

Our study uses content analysis to measure the degree of IRD. Consistent with prior studies [25], we apply a non-weighted disclosure approach to measure IRD by analyzing the existence of each item of disclosure index from the annual reports. We assign a score of 1 if the company disclosed disclosure index's item and 0 if the disclosure item was not found. 
Table 1. Integrated Reporting Item

\begin{tabular}{|c|c|}
\hline \multicolumn{2}{|c|}{ Disclosure item } \\
\hline (1) Organizational overview and External Environment & (2) Governance \\
\hline $\begin{array}{l}\text { Mission and vision statement. } \\
\text { General explanation about organizational culture, ethics, or values. } \\
\text { Code of conduct. } \\
\text { Ownership or operating structure. } \\
\text { Competitive landscape \& marketing positioning. } \\
\text { The number of employees. } \\
\text { Countries in which the organization operates. } \\
\text { Legal factors. } \\
\text { Political factors. } \\
\text { Social factors. } \\
\text { Market forces. } \\
\text { Key stakeholders. } \\
\text { Environmental factors. }\end{array}$ & $\begin{array}{l}\text { Board of directors list. } \\
\text { Board experience or skills. } \\
\text { Culture, ethics \& values are reflected in its use of and effects on } \\
\text { the capital. } \\
\text { Actions were taken to monitor strategic directions. } \\
\text { Compensation policies. }\end{array}$ \\
\hline (3) Business Model & (4) Risk and Opportunities \\
\hline $\begin{array}{l}\text { Key inputs. } \\
\text { Product differentiation. } \\
\text { Delivery channels and marketing. } \\
\text { After-sale service. } \\
\text { Innovation. } \\
\text { Employee training. } \\
\text { Key products and services. } \\
\text { GHG emission. } \\
\text { Water waste. } \\
\text { Employee morale. } \\
\text { Organizational reputation. } \\
\text { Revenue, cash flows. } \\
\text { Customer satisfaction. } \\
\text { Increase in capital (create value). } \\
\text { Decrease in capital (diminish value). } \\
\end{array}$ & $\begin{array}{l}\text { Internal/external risk. } \\
\text { Internal/external opportunities. }\end{array}$ \\
\hline (5) Strategy and Resource Allocation & (6) Performances \\
\hline $\begin{array}{l}\text { Short, medium and long term strategic objectives (without time } \\
\text { frame). } \\
\text { Short, medium and long term strategic objectives (with time } \\
\text { frame). } \\
\text { Strategies it has in place or intends to implement to achieve those } \\
\text { strategic objectives. } \\
\text { The measurement of achievements and target outcomes. } \\
\text { An understanding of the organization's ability to adapt to change } \\
\text { to achieve goals. } \\
\text { The link between strategies and key capitals. }\end{array}$ & $\begin{array}{l}\text { KPIs that present financial measures. } \\
\text { The KPIs that combine financial measures with other components } \\
\text { (i.e., The ratio of GHG emissions to sales). } \\
\text { Linkages between past and current performance. } \\
\text { Comparison between regional/industrial benchmarks. } \\
\text { Financial implications of significant effects on other capital. }\end{array}$ \\
\hline (7) Outlook & \\
\hline $\begin{array}{l}\text { Expectations about future or explanations about uncertainties. } \\
\text { Forecast about KPIs. } \\
\text { Assumptions related to those forecasts. } \\
\text { Linkages between current performance and the organization's } \\
\text { outlook. }\end{array}$ & \\
\hline
\end{tabular}

Source: [24] 


\subsection{Independent Variables}

The independent variables include four attributes of firm's board namely size, independence, activity and gender diversity. The operationalizations for the independent variables are as per Table 2.

Table 2. Definition and operationalization of independent variables

\begin{tabular}{|c|c|c|}
\hline $\begin{array}{c}\text { Independent } \\
\text { Variables }\end{array}$ & Definition & Operationalization \\
\hline BSIZE & $\begin{array}{c}\text { Size of the board } \\
\text { of directors }\end{array}$ & $\begin{array}{c}\text { Total number of } \\
\text { executive and } \\
\text { non-executive members } \\
\text { on the board of directors } \\
{[14][26][27]}\end{array}$ \\
\hline BIND & $\begin{array}{c}\text { Independence of } \\
\text { the board of } \\
\text { directors }\end{array}$ & $\begin{array}{c}\text { Percentage of } \\
\text { non-executive directors } \\
{[28][14][26]}\end{array}$ \\
\hline BACT & $\begin{array}{c}\text { Activity of the } \\
\text { board }\end{array}$ & $\begin{array}{c}\text { The number of meetings } \\
\text { held during each } \\
\text { financial year [24][27] }\end{array}$ \\
\hline BDIVERSITY & $\begin{array}{c}\text { Proportion of } \\
\text { women directors }\end{array}$ & $\begin{array}{c}\text { The percentage of } \\
\text { women on the board of } \\
\text { directors [28][14] }\end{array}$ \\
\hline
\end{tabular}

\subsection{Control Variables}

To test the hypotheses, our study controls four variables of firm-specific characteristics. First, our study controls for firm size as prior research document significant and positive relationship between firm size (SIZE) and the degree of voluntary disclosure[29,30]. We measure SIZE by natural $\log$ the total assets of the firm. Second, we control for firm's profitability (PROFITABILITY). Consistent with previous studies, we use return on assets (ROA) as a measure for PROFITABILITY [14][31,32]. Third control variable is firms growth (GROWTH), measure by the market to book ratio. Frias-Aceituno et al. [12] argue that high growth firms are more likely to disclose more information to their stakeholders in order to mitigate information asymmetry problems. Fourth, we control firm's leverage (LEVERAGE). It is because firms with higher level of debts are more willing to disclose information voluntarily in order to reduce agency costs and cost of capital [33].

\section{Results}

\subsection{Descriptive Analysis}

The descriptive statistics of the variables analyzed are presented in Table 3.

The IRD ranges from 18.00 to 44.00 . This finding suggests that the sample has a good IR since the mean of IRD is 34.15. In terms of board characteristics, the minimum and maximum numbers of directors in the sample are 6 and 14 respectively. The average number of board directors is 9.83. Consistent with [34], this study supports the view that the number of directors should not exceed 14 members in order to ensure the effectiveness of directors' role in the financial institutions. With regards to independence directors, on average, $51 \%$ of the board directors are independent members and it ranges from $30 \%$ to $69 \%$. It seems that the frequency of board meeting ranges from 5 times to 21 times. The mean of board meeting frequency of the sample is 12.33 times. In line with [35], it suggests that financial institutions have a more frequent board meeting because of its complex business environment. On average, $14 \%$ of the board directors in financial institutions are women directors and range from $0 \%$ to $38 \%$.

For the control variables, the average total assets of the sample (SIZE) are RM283, 955.41 million and range from RM43, 692.03 million and RM765, 301.77 million. In relation to PROFITABILITY measured by ROA, the minimum and maximum ROA are RM0.008 and RM1.442 respectively. On average, the ROA of the sample is RM0.975. This study suggests that the GROWTH measured by the market to book ratio ranges from 0.009 and 0.003 with an average growth of 0.0014. The LEVERAGE indicates that on average $11 \%$ of the equity of the sample is financed through liabilities and ranges between around $7 \%$ and $17 \%$ of total equity. This finding proposes that the sample has a low leverage ratio.

Table 4 tabulates the Pearson correlation coefficients for the variables of the study. It suggests that in general IRD was positively related to diversity and size of the financial institutions. Since the results in Table 4 indicate that none of the correlation coefficients of the variables exceeds 0.7 , the sample had no multicollinearity problem. 
Table 3. Descriptive Statistics

\begin{tabular}{|c|c|c|c|c|}
\hline \multicolumn{3}{|c|}{ Table 3. Descriptive Statistics } & Max & Mean \\
\hline Variables & Min & 44.00 & 34.15 \\
\hline IRD & 18.00 & 14.00 & 9.83 \\
\hline BSIZE & 6.00 & 0.69 & 0.51 \\
\hline BIND & 0.30 & 21.00 & 1.99 \\
\hline BACT & 5.00 & 0.38 & 0.12 & 0.14 \\
\hline BDIVERSITY & 0.00 & $765,301.77$ & $283,955.41$ \\
\hline SIZE & $43,692.03$ & 1.44 & 0.97 \\
\hline PROFITABILITY & 0.008 & 0.003 & $195,900.72$ \\
\hline GROWTH & 0.0009 & 16.91 & 0.41 \\
\hline
\end{tabular}

Table 4. Pearson Correlation Coefficient

\begin{tabular}{|c|c|c|c|c|c|c|c|c|c|}
\hline & IRD & BSIZE & BIND & BACT & BDIVERSITY & SIZE & PROFITABILITY & GROWTH & LEVERAGE \\
\hline IRD & 1 & & & & & & & & \\
\hline BSIZE & -0.131 & 1 & & & & & & & \\
\hline BIND & -0.174 & 0.252 & 1 & & & & & & \\
\hline BACT & 0.193 & $\begin{array}{c}0.382 \\
*\end{array}$ & $\begin{array}{c}0.345 \\
*\end{array}$ & 1 & & & & & \\
\hline BDIVERSITY & $\begin{array}{c}0.389 \\
*\end{array}$ & $\begin{array}{c}-0.460 \\
* *\end{array}$ & $\begin{array}{c}-0.523 \\
* *\end{array}$ & -0.311 & 1 & & & & \\
\hline SIZE & $\begin{array}{c}0.479 \\
* *\end{array}$ & $\begin{array}{c}0.319 \\
*\end{array}$ & 0.239 & $\begin{array}{c}0.423 \\
* *\end{array}$ & 0.264 & 1 & & & \\
\hline PROFITABILITY & 0.058 & 0.279 & -0.303 & $\begin{array}{c}0.343 \\
*\end{array}$ & -0.235 & -0.127 & 1 & & \\
\hline GROWTH & 0.186 & -0.007 & -0.190 & $\begin{array}{c}0.346 \\
*\end{array}$ & -0.019 & 0.091 & $\begin{array}{c}0.552 \\
* *\end{array}$ & 1 & \\
\hline LEVERAGE & 0.087 & -0.270 & 0.066 & -0.268 & 0.245 & 0.055 & -0.271 & 0.301 & 1 \\
\hline
\end{tabular}

*Correlation is significant at the 0.05 level (2-tailed).

$* *$ Correlation is significant at the 0.01 level (2-tailed). 


\subsection{Multiple Regression Analysis}

In determining whether board of directors characteristics might influence the disclosure of IR, this study used the following model:

IRDi, $t=\alpha+\beta 1$ BSIZEi $, t+\beta 2 B I N D i, t+\beta 3$ BACTi, $t+$ $\beta 4$ BDIVERSITYi,$t+\beta 5$ SIZEi,$t+\beta 6$ PROFITABILITYi,$t$ $+\beta 7$ GROWTHi, $t+\beta 8$ LEVERAGEi $, \mathrm{t}+\xi \mathrm{i}, \mathrm{t}$

Table 5 reports the results of the multiple regression analysis of firm's board attributes and control variables on IRD.

The results in Table 5 show that the model used can explain around $51 \%$ of the variables that might influence IRD and the F-stat value for the model is significant at 0.01 level. This study suggests that the only one of the board of directors attributes, BSIZE affects IRD. In contrast with [36], it is found that board size has a negative significant influence on IRD. This finding supports the argument proposed by [15] that smaller board size is more effective due to communication and coordination issues as well as higher conflicts and inflexibility in the decision-making process. Consistent with [37][34], this study opines that the challenges in having larger board size outweigh its benefits.

Table 5. Multiple Regression Analysis

\begin{tabular}{|c|c|c|c|}
\hline & $\beta$ & $\mathrm{t}$ & Sig. \\
\hline CONSTANT & -61.044 & -1.868 & $.071^{*}$ \\
\hline BSIZE & -0.933 & -1.875 & $.070^{*}$ \\
\hline BIND & 2.107 & 0.216 & 0.831 \\
\hline BACT & -0.239 & -1.019 & 0.316 \\
\hline BDIVERSITY & 11.680 & 0.983 & 0.333 \\
\hline SIZE & 10.452 & 3.117 & $0.004^{* * *}$ \\
\hline PROFITABILITY & -1.171 & -0.425 & 0.674 \\
\hline GROWTH & 5269.148 & 2.337 & $0.026 * *$ \\
\hline LEVERAGE & -1.953 & -3.994 & $0.000^{* * *}$ \\
\hline Adj. R Square & 0.508 & & \\
\hline F value & $6.032 * * *$ & & \\
\hline
\end{tabular}

*Correlation is significant at the 0.10 level (2-tailed).

**Correlation is significant at the 0.05 level (2-tailed).

****Correlation is significant at the 0.01 level (2-tailed).

It appears that other board attributes have no influence on IRD. Unlike [28], this study suggests that voluntary disclosure such as IRD is not influenced by board independence (BIND). It could be due to the view that since independent directors are crucial in monitoring managerial activities and protect the interest of shareholders, decision related to IRD is not regarded as having a negative impact on shareholders' interest [34]. The frequency of meeting has no influence on IRD. This finding indicates that the frequency of board meetings may not be beneficial in determining the level of IRD since the directors need to focus more on other productive activities. Unlike [38],[39],[28], voluntary disclosure including IRD is not influenced by the diversity of the board. Even though female directors have a different personality, communication style, educational background and career experience [40], this study indicates that female directors are indifferent from male directors in reinforcing the stakeholders' involvement mechanisms which will lead to the improvement in the reliability of corporate reports. Thus, the view of the directors towards IRD is not determined by the gender of the directors.

This study considers four control variables, namely the size of the financial institutions, profitability, growth, and leverage. Except for profitability, the other control variables have a significant influence on the level of IRD. Consistent with [41], IRD is positively and significantly influenced by SIZE. Due to resources available, larger banking institutions have no constraint in preparing an integrated report. This study supports the argument by [42] which is growing institutions have a higher level of IRD since financial institutions will benefit through greater access to resources. Thus, growth has a positive and significant influence on IRD. Similar to [43], leverage level has a negative influence on IRD. Financial institutions with higher leverage tend to have a lower level of IRD. In contrast with [44], this study suggests that profitability has no influence on IRD. This finding is in line with [41][43].

\section{Conclusions}

Our study examines how board of directors' attributes affect the degree of IRD in Malaysia. Using a sample of Malaysian commercial banks listed on Bursa Malaysia covering the period from 2013 to 2017, we find one of the board's attributes; BSIZE affects IRD. Specifically, the findings indicate that there is a significant and negative relationship between BSIZE and IRD. The results suggest that Malaysian commercial banks with a smaller number of board members are more likely to have higher degree of IRD. In addition, the findings reveal that the degree of IRD does not associated with the composition of independent directors on the board, board activity and diversity. The results signal and reflect the level of the knowledge and awareness towards IR among Malaysian listed firms in particular commercial banking institutions are still low. In fact, IR will give an additional burden on the existing reporting requirements for the listed firms.

Our study however is subject to a number of limitations. First, the results of this study cannot be generalized because our study only focuses on eight commercial banking institutions as to match with the data available in Datastream. Second, our study only examine four attributes of board of directors. Future research might explore other board's attributes such as role of CFO in 
influencing IRD. Third, the study is only based on secondary data trace from annual report and datastream. Future research might expand this work by examining the degree of IRD from other sources such as websites, press releases, and prospectuses.

In summary, this study provides some implications for both theory and practice. This is among a few studies that examine the impact of board of directors on IRD in Malaysia setting. Thus, the results provide assistance in establishing a preliminary framework to empirically examine the effect of board of directors in promoting IRD in emerging markets like Malaysia. Second, the results should be of interest to regulators to assist them to improve the roles of firms' board in promoting IRD for better corporate transparency.

\section{REFERENCES}

[1] J. Jensen and N. Berg, "Determinants of Traditional Sustainability Reporting versus Integrated Reporting: An Institutional Approach,” Business Strategy and Environment, vol. 21, pp. 299-316, 2012.

[2] Online available from http://www.theiirc.org/international-ir -framework/

[3] G.-S. Isabel-Maria and N.-G. Ligia, "Integrated Information and the Cost of Capital," International Business Review, vol. 26, pp. 959-975, 2017.

[4] L.Songini, A. Pistoni, P. Tettamanzi, F. Fratini, and V.Minutiello, "Integrated reporting quality and BoD characteristics: an empirical analysis," Journal of Management and Governance, 1-42, 2021.

[5] F.Vitolla, N. Raimo, and M.Rubino, "Board characteristics and integrated reporting quality: an agency theory perspective," Corporate Social Responsibility and Environmental Management, 27(2), 1152-1163, 2020.

[6] E. C. M. Cheng and S. M. Courtenay, "Board composition, regulatory regime and voluntary disclosure,” Int. j. account. educ. res., vol. 41, no. 3, pp. 262-289, 2006.

[7] J.-M. Prado-Lorenzo, I. Gallego-Alvarez, and I. M. Garcia-Sanchez, "Stakeholder engagement and corporate social responsibility reporting: the ownership structure effect," Corp. Soc. Responsibility Environ. Manage., vol. 16, no. 2, pp. 94-107, 2009.

[8] R. M. Haniffa and T. E. Cooke, "The impact of culture and governance on corporate social reporting," J. Account. Public Policy, vol. 24, no. 5, pp. 391-430, 2005.

[9] J.-M. Prado-Lorenzo and I.-M. Garcia-Sanchez, "The role of the board of directors in disseminating relevant information on greenhouse gases," J. Bus. Ethics, vol. 97, no. 3, pp. 391424, 2010.

[10] Integrated Reporting in Malaysia, Accountants Today, 27(4). Accountants Today, 2014.

[11] A.A. Elamer, C.G. Ntim, H.A. Abdou, A.M., Zalata, and M. Elmagrhi, "The impact of multi-layer governance on bank risk disclosure in emerging markets: The case of Middle
East and North Africa," In Accounting Forum, vol. 43, no. 2, pp. 246-281, 2019.

[12] R. G. Eccles and M. P. Krzus, One Report: Integrated Reporting for a Sustainable Strategy. John Wiley \& Sons, 2010.

[13] W. Stubbs and C. Higgins, Sustainability and Integrated Reporting: A Study of the Inhibitors and Enablers of Integrated Reporting. Institute of Chartered Accountants in Australia, 2012.

[14] J. V. Frias-Aceituno, L. Rodriguez-Ariza, and I. M. Garcia-Sanchez, "The role of the board in the dissemination of integrated corporate social reporting: The role of the board in the dissemination of integrated report," Corp. Soc. Responsibility Environ. Manage., vol. 20, no. 4, pp. 219233, 2013.

[15] M.C.Jensen, "The modern industrial revolution, exit, and the failure of internal control systems," the Journal of Finance, 48(3), 831-880, 1993.

[16] M.Kılıç, and C. Kuzey, "Determinants of forward-looking disclosures in integrated reporting," Managerial Auditing Journal, 2018.

[17] M.Lipton, and J.W. Lorsch, "A modest proposal for improved corporate governance," The business lawyer, 59-77, 1992.

[18] M.Akhtaruddin, M.A. Hossain, M. Hossain, and L. Yao, "Corporate governance and voluntary disclosure in corporate annual reports of Malaysian listed firms", Journal of Applied Management Accounting Research, vol. 7 no. 1, pp. 1-19, 2009.

[19] M. Wang, and K. Hussainey, "Voluntary forward-looking statements driven by corporate governance and their value relevance", Journal of Accounting and Public Policy, Vol. 32 No. 3, pp. 26-49, 2013.

[20] W. Qu, M.S. Ee, L. Liu, V. Wise, and P. Carey, "Corporate governance and quality of forwardlooking information: evidence from the Chinese stock market", Asian Review of Accounting, Vol. 23 No. 1, pp. 39-67, 2015.

[21] G.Giannarakis "Corporate governance and financial characteristic effects on the extent of corporate social responsibility disclosure," Social Responsibility Journal, 10(4,)569-590, 2014.

[22] M.A.Naseem, R.U. Rehman, A. Ikram, and F. Malik, "Impact of board characteristics on corporate social responsibility disclosure," Journal of Applied Business Research (JABR), 33(4), 801-810, 2017.

[23] W. Ben-Amar, M. Chang, and P. McIlkenny, "Board gender diversity and corporate response to sustainability initiatives: Evidence from the carbon disclosure project," Journal of business ethics, 142(2), 369-383, 2017.

[24] M. Kilı̧ and C. Kuzey, "Assessing current company reports according to the IIRC integrated reporting framework," Meditari account. res., vol. 26, no. 2, pp. 305-333, 2018.

[25] K. Krippendorff, Content Analysis- An Introduction to Its Methodology. Beverly Hills, CA: Sage Publications, 2004.

[26] H. A. Riyadh, E. G. Sukoharsono, and S. A. Alfaiza, "The impact of corporate social responsibility disclosure and board 
characteristics on corporate performance," Cogent bus. manag., vol. 6, no. 1, p. 1647917, 2019.

[27] P. Velte, "Does board composition have an impact on CSR reporting?," Probl. Perspect. Manag., vol. 15, no. 2, pp. 1935, 2017.

[28] H. O. Anazonwu, F. C. Egbunike, and A. Gunardi, "Corporate board diversity and sustainability reporting: A study of selected listed manufacturing firms in Nigeria," Indones. j. sustain. account. manag., vol. 2, no. 1, p. 65, 2018.

[29] F. A. Gul and S. Leung, "Board leadership, outside directors' expertise and voluntary corporate disclosures," J. Account. Public Policy, vol. 23, no. 5, pp. 351-379, 2004.

[30] L. Luna Sotorrío and J. L. Fernández-Sánchez, "Corporate Social Reporting for Different Audiences: The case of multinational corporations in Spain," Corporate Social Responsibility and Environmental Management, vol. 17, pp. 272-283, 2010.

[31] C. Marston and A. Polei, "Corporate reporting on the Internet by German companies,” Int. J. Acc. Inf. Syst., vol. 5, no. 3, pp. 285-311, 2004.

[32] A. Prencipe, "Proprietary costs and determinants of voluntary segment disclosure: evidence from Italian listed companies," Eur. Account. Rev., vol. 13, no. 2, pp. 319-340, 2004.

[33] M. C. Jensen and W. H. Meckling, "Theory of the Firm: Managerial Behaviour, Agency Costs and Ownership Structure," Journal of Financial Economics, vol. 3, no. 4, pp. 305-360, 1976.

[34] T. Wang and C. Hsu, "Board composition and operational risk events of financial institutions," J. Bank. Financ., vol. 37, no. 6, pp. 2042-2051, 2013.

[35] S. K. Johl, S. Kaur, and B. J. Cooper, "Board characteristics and firm performance: Evidence from Malaysian public listed firms," J. Econ. Bus. Manag., vol. 3, no. 2, pp. 239-243, 2015 .
[36] A. Amran, S. P. Lee, and S. S. Devi, "The influence of governance structure and strategic corporate social responsibility toward sustainability reporting quality: Influence of governance structure and strategic CSR on sustainability reporting quality," Bus. Strat. Environ., vol. 23, no. 4, pp. 217-235, 2014.

[37] Q. Liang, P. Xu, and P. Jiraporn, 'Board characteristics and Chinese bank performance', J. Bank. Financ., vol. 37, no. 8, pp. 2953-2968, 2013.

[38] R. B. Adams, J. de Haan, S. Terjesen, and H. van Ees, "Board diversity: Moving the field forward", Corp. Gov. Int. Rev., vol. 23 , no. 2 , pp. 77-82, 2015.

[39] H. Al-Shaer and M. Zaman, "Board gender diversity and sustainability reporting quality," J. contemp. account. econ., vol. 12 , no. 3, pp. 210-222, 2016.

[40] L. Liao, L. Luo, and Q. Tang, "Gender diversity, board independence, environmental committee and greenhouse gas disclosure," Br. account. rev., vol. 47, no. 4, pp. 409424, 2015.

[41]E. K. Ghani, J. Jamal, E. Puspitasari, and A. Gunardi, "Factors influencing integrated reporting practices among Malaysian public listed real property companies: a sustainable development effort," Int. j. manag. financ. account., vol. 10, no. 2, p. 144-162, 2018.

[42] H. A. Macias and A. Farfan-Lievano, "Integrated reporting as a strategy for firm growth: multiple case study in Colombia," Meditari account. res., vol. 25, no. 4, pp. 605628, 2017.

[43] M. K1lıc and C. Kuzey, "Determinants of forward-looking disclosures in integrated reporting," Manag. Audit. J., vol. 33, no. 1, pp. 115-144, 2018.

[44] N. Buitendag, G. S. Fortuin, and A. Laan, "Firm Characteristics and Excellence in Integrated Reporting," South African Journal of Economic and Management Sciences, vol. 20, no. 1, pp. 1-8, 2017. 